\title{
Analysis Of Family Empowerment Based Agriculture In Increasing Family Economy And Child Growth
}

\author{
Sylva Alkornia, Niswatul Imsiyah, and Linda Fajarwati \\ Dosen Program Studi Pendidikan Luar Sekolah FKIP Universitas Jember \\ sylva.fkip@unej.ac.id, Niswatul.fkip@unej.ac.id,linda.fkip@unej.ac.id
}

\begin{abstract}
This articel aims to (1) analyze a variety of ideal family empowerment based agricultural activities and solutions to be used by the community to improve the family economy and child growth, and (2) implement an family empowerment based agriculture program through non-formal education as an ideal solution. This study used a qualitative descriptive method with data collection carried out by means of interviews and documentation on subjects consisting of village heads, village officials, and community village. The results of the study show that family empowerment basedagriculture programs such as early childhood education, equality, literacy, life skills, and counseling are the ideal solutions for many community empowerment programs that have been identified. These programs can improve the quality of life of the community and can disseminate the existence of agriculture-based family empowerment programs through non-formal education in supporting the objectives of national education development in Indonesia
\end{abstract}

Keywords: family empowerment, family economy, child growth

\section{Introduction}

Goals of education in the Indonesia republic, National Education System Law No. 20 of 2003 is to improve the quality of human beings who are faithful, devoted to God Almighty, noble character, discipline, hard work, intelligent, and skilled and healthy physically and spiritually. The aim of national education is realized through the implementation of ideal education, especially through non-formal education. In realizing it, it takes a short time, so that it is necessary to analyze all the ideal learning needs and be implemented immediately in overcoming the problems of people's lives.

Geographically, Sukorambi village is a village located at the foot of Mount Argopuro, precisely in the Sukorambi sub-district of Jember. The area of 1,112.65 hectares (Ha) consists of 3 (three) hamlets, namely Krajan Hamlet, Manggis Hamlet and Curahdami Hamlet with the northern boundaries of Durjo Plantation, the east is Kebon Agung Village, the south is Sempusari, and the west is Serut Village. The number of rukun (RW) is 27 (twenty seven), while the number of neighborhood units is 73 (seventy three). the population of Sukorambi Village was 11,597 people or 4,617 households consisting of 6,046 male population and 5,551 female population (BPS, 2017). The number of kindergarten level schools there are 4 schools have 9 teachers and RA there are 7 schools have 22 teachers, there are 6 elementary schools have 59 schools and non dispendik elementary schools there are 2 schools have 19 teachers, there are 2 junior secondary schools have 29 schools and 29 non-dispendic teachers there are 2 schools that have 19 teachers, there are 2 high school level schools with 11 teachers, and there are 5 Islamic boarding schools/TPQ. From these data, the total school-aged population reached 9,997 people for those who did not/never attended school totaling 
1,789 people, did not complete elementary school 2,179 people, SD/MI numbered 4,386 people, junior high schools/MTS numbered 947 people, high school/MA numbered 554 people , SMK numbered 54 people, D1/D2 numbered 12 people, D3 numbered 10 people, D4/S1 numbered 61 people, and S2/S3 numbered 5 people.

Sukorambi village is known as an agrarian village. Has natural potential that is quite prospective for economic development in the region at the village level. In accordance with the economic potential of the village, the economy in Sukorambi Village still relies on the agricultural sector as the base and drive the economy in the region. Agriculture as a leading sector to date still has a dominant and strategic war for economic development both as a provider of foodstuffs for processed products, increasing village and community income and absorbing significant amounts of labor. The current resources which are superior economic potentials are in agriculture with a number of products produced including rice, corn, soybeans, sweet potatoes, long beans, peanuts, vegetables, and other secondary crops.

Based on the results of preliminary observations that the numbers that did not/had never attended school and did not graduate from elementary school in Sukorambi village were quite large, while formal education services were still not comparable with the number of school-age residents. Meanwhile non-formal education services have not been seriously addressed. While the facilities and infrastructure in the Sukorambi village environment strongly support the implementation of nonformal education programs. Therefore we need a good management in non-formal education programs, so that it can help in motivating to overcome the problems of life of the surrounding community.

Some of the obstacles encountered by the Sukorambi village community based on the results of observations and interviews are the lack of activities that support the problem of their lives, one of which can foster the attitude of the people who like to study science, environment and technology. This can be given through the empowerment activities the results that want to be achieved by a social change that is a community that is empowered, has the knowledge and ability to fulfill their needs.

The formulation of the problem in this study is (1) what agricultural-based family empowerment activities can be immediately given as the ideal solution to the problem of improving the family economy and child development? and (2) what nonformal education programs are ideal in overcoming the problem of agricultural-based family empowerment through non-formal education?

Education in Indonesia has an important role to play in helping someone achieve his success. Education is basically a human effort to improve knowledge, both obtained from formal and non-formal institutions. Especially through non-formal education that aims to change mental attitudes and thinking patterns of citizens to have activity and creativity in various fields of life, have a set of knowledge and skills needed as a condition to improve quality and standard of living. Therefore, to achieve this, the right non-formal education objectives are needed. The purpose of education 
will determine success in the process of forming a human person, of course balanced with other elements in non-formal education.

Non-formal education has a role to help the community in problem solving efforts (Rusmin Husain, 2011). One of the targets of change that PLS wants to achieve in community development is the growth of a learning society. People like to learn contain the meaning of changing society from a pseudo-life situation, which is meant by society in a dreaming society towards planning society.

Non formal education can function to help accelerate the development program required by a large number of skilled workers in various fields, who cannot be served quickly and permanently by formal education programs. In order to expand the dissemination of non-formal education programs, the government has accelerated the service process in a shorter time. From the point of view of non-formal education policy, one of the main objectives of the expansion and equitable distribution of educational opportunities is to change the mental attitude and thinking patterns of citizens to have activity and creativity in various fields of life, having a set of knowledge and skills needed as a condition to improve quality and standard of living. Non-formal education is seen as one of the factors to help solve the problem of education in Indonesia. Non-formal education is seen as one of the most important and strategic factors in order to realize directives for the achievement of a resilient, resilient and transient society. Therefore, efforts need to be made to expand non-formal education programs to provide opportunities for citizens to improve their lives. However, there are still many obstacles encountered in meeting the learning needs of the community. Illiteracy is an obstacle to the development of society to carry out development in the global era and youth as a group in society which is a potential for development and for generations to come there has been no guidance so that many droup out means waste in education which results in illiteracy return, or cannot utilize knowledge knowledge and reduce public trust in formal education in school.

Analyzing family empowerment is certainly inseparable from the components of non-formal education which include (1) learning citizens, (2) learning yeast, (3) learning resources, (4) activity groups, (5) learning officials, (6) places learning, (7) learning facilities, (8) learning funds, (9) learning activities programs, (10) learning outcomes (Sylva Alkornia, 2018).

Learning citizens are citizens who need and want to learn. Citizens learning is one component in teaching, in addition to educator factors, goals, and teaching methods. As one component, it can be said that citizen learning is the most important component among other groups. Basically citizens learn is a decisive element in the teaching and learning process. Without the learning community, the teaching process will not actually occur. Because the citizens of learning who need teaching and not educators, educators only try to meet the needs of the learning population. Without citizens learning, educators will not be able to teach. So that citizens learn is an important component in the relationship of this teaching and learning process. The learning community consists of the community because they are the ones who need an 
increase in knowledge education and not a few attitude changes. Learning citizens consist of children, adolescents and adults.

Learning resources are learning citizens who have enough education to devote themselves to helping implement community education activities in study groups. Citizens who have good strength in the fields of knowledge, skills, attitudes and are able and willing to divert what they have in the learning community through the learning process. Learning resources can be said as people who feel responsible for improving human capabilities in their environment. They are human beings who are not ignorant of ignorance. Learning resources are not only those who have a diploma at a certain level of education, those who do not even go to school, but have excellence and want to share these advantages with others can be a source of learning. Learning resources are also called tutors, technical sources.

Pamong Belajar is a community leader who is able and willing to foster, guide, direct and organize learning programs for the surrounding community. Pamong learns given the tasks, responsibilities, authority and rights to carry out teaching and learning activities in the framework of developing models and making demonstrations and evaluations in order to control the quality and impact of implementing educational programs outside of school. Pamong Belajar that will guarantee the learning process for learning citizens who have decided to participate in certain programs. Pamong learns to live around learning residents so that they are easy to communicate and support each other; Pamong Belajar is not a structural officer of the government, but officers are accepted by the learning citizens as their mentors

Learning tools are tools or materials used in the learning process. materials and tools that exist in the community, which can be used to support the learning process. Learning facilities in their form can be in the form of books, sheets, buildings, natural resources, animals, plants and anything that can be added to, increase knowledge and knowledge of the learning community.

The place of learning is a place for learning. Is a place where learning is possible; It can be in the form of a house, a meeting place, a place of worship, a village hall, or a building that is no longer used but still allows use. Learning can occur anywhere, as long as the people learn, learning resources and tutors learn that the place is appropriate to support the achievement of desired learning outcomes. The learning place can also be in the form of a field, a historical place. That is why it is said that PLS does not demand buildings, but opportunities to guarantee the learning process.

The source of learning funds is money or other material that can be cashed in to support the implementation of learning programs that have been compiled by the tutors together with learning resources and learning citizens. Learning funds can be sourced from government, community leaders, entrepreneurs in the environment where residents learn to live, or those sourced from self-learning residents or from community members in general. 
Yeast Learning is commonly known as learning motivation or learning stimulation. Stimulation that is able to arouse the learning spirit of the learning community, so that the learning process occurs; It happens without coercion, bluffing but because of the awareness of the citizens of learning and the power of the people there is the learning yeast itself. Learning yeast is a powerful force that comes from outside the learning community and which actually exists in the learning community which causes the learning community to be happy, happy and persistent to continue learning. This yeast causes the learning process to continue until the goal is reached. Yeast Learning aims to motivate learning citizens who feel less confident in the learning process so that the learning community can be motivated and excited in the learning process. In the learning process, in the learning process Learning citizens are given learning through a non-formal education unit program, so the learning citizens do not feel that they are learning. Besides that, the learning citizens provide a personal approach to learning citizens who have problems in the learning process.

Learning outcomes are a series of knowledge, skills and attitudes that are mastered by the learning community after a certain learning process is passed in a certain period of time. The meaningfulness of learning outcomes for improving the quality of life and the lives of learning citizens is a benchmark of success. Learning outcomes that can immediately improve the lives of learners, are learning yeasts for further proces.

\section{Research Method}

This study uses descriptive qualitative research methods. This is because research seeks to obtain an in-depth picture of learning needs and find an ideal learning needs assistance program for people in Sukorambi village. According to Patton (dalam Budi Puspo Priyadi, 2009), the reason for using this trigulation type is because there are weaknesses in the single data collection strategy. The subjects of the study consisted of 1 Head of the Village, 1 Village Head, 4 poor people. The technique of collecting data uses interviews, observation, and documentation. The research instrument was implemented using a list of interview questions, notebooks, and documents. Data analysis techniques that will be used in this study through data reduction, data testing, and conclusion verification.ssing. Learning only to know will be less meaningful for the learning community.

\section{Research Results and Discussion}

Sukorambi is one of the urban villages in Sukorambi sub-district, Jember. Geographically located located $1354 \mathrm{~m} 2$ above sea water located at the foot of Mount Argopuro and including the plateau with a distance from the district capital of $15 \mathrm{~km}$. The area is 1.112 .65 hectares (ha) consisting of 3 (three) hamlets, namely Krajan Hamlet, Manggis Hamlet and Curahdami Hamlet with the northern boundaries of the Village is Durjo Plantation, east of the village is Kebon Agung village, south of the 
village is Sempusari, and west of the village is Serut village. The land area consists of 456 rice fields, 27 fields, and 111 buildings along with the yard. The population is 11,256 people, consisting of 5,574 male souls and 5,682 female souls.

The livelihoods of Sukorambi residents consist of 1,328 people in agriculture, 61 in industry/handicrafts, 218 in construction, 301 in trade, 8 in transportation, 172 in other fields. The education level of the population consists of population education consisting of 1,789 people not/never attended school, 1,279 people not graduating from elementary school, 4,386 graduating elementary school/MI, 947 people graduating from junior high school/MTs, and 554 graduating from high school, 54 graduating from vocational school 12 people graduated D1/D2, 10 people graduated from D3, 64 people graduated D4/S1, and 5 people graduated S2. The number of Drop Outs or DOs is still relatively high, with 6,268 people not yet being treated by nonformal education services. When viewed from the potential of educational institutions, Sukorambi village has 11 kindergarten/RA education institutions with 441 students, 8 elementary/MI educational institutions with 1,157 students, 4 junior secondary/MTs educational institutions with 804 students, and 2 senior secondary education institutions with number of 188 students. Other potential non-formal education institutions exist in the religious field, namely 2 Islamic boarding schools and 3 Alquran educational sites.

The unemployment condition of Sukorambi villagers consists of 2,315 people, the number of workforce aged (15-55 years), 2,483 people, the number of people aged (15-55 years) who are still in school, 987 the number of people aged (15-55 years) who are housewives stairs. 5,098 people who are full-time (15-55 years old), and 401 people are aged (15-55 years) who work erratically.

The economic situation of the Sukorambi village community is relatively poor, this can be seen from the data on the number of houses and poor people, namely 1,464 classified as Poor Households (RTM) and the Poor population as many as 5,178.

In general Sukorambi village infrastructure condition is relatively good. Intervillages are connected by paved roads, block roads, and makadam roads and dirt roads that are in good condition. There are inter-village transportation facilities (RW) that are passed by village transportation and motorcycle taxi. The availability of clean water, means of communication, drainage, lighting and infrastructure of the village office is relatively good.

Based on the results of interviews with a number of respondents can be identified namely (1) introduction of problems / needs and potential as well as awareness, (2) problem formulation and priority setting, (3) identification of alternative problem solving / idea development, (4) selection of problem solving alternatives the most appropriate, (5.) planning the implementation of ideas and presentation of activity plans, (6) implementing organizing, (7) monitoring and directing activities, and (8) evaluation and follow-up plans.

Introduction of problems/needs and potential, with the intention to gather information about the existence of the environment and society in general. Problem 
formulation and priority setting to obtain formulations on the basis of local problems and potential. Identify alternative problem solving or developing ideas to discuss various possible solutions to problems through community consultation. Selection of alternative solutions that are most appropriate in accordance with the capabilities of the community and available resources in relation to self-help. Planning the implementation of ideas with solving these problems in a concrete manner so that their implementation can be easily monitored. Presentation of activity plans to get input for improvement at a larger level. Implementation and organization of the community according to the needs and level of community development. Monitoring and directing activities to see their suitability with the plans that have been prepared. And evaluation activities and follow-up plans to see results as expected, problems that have been resolved, emergence of further problems, etc.

Based on the PRA (Participatory Rural Appraisal) approach, it can be determined the learning needs of the Sukorambi community, especially those relating to meeting the learning needs in the field of education that can help overcome life problems, namely (1) the higher number of droup out and found that there are still many can read, write and count or be termed an illiterate society so it requires an effort to optimize the quality and reach of non-formal education services, (2) need to find new education learning methods to support early childhood development, considering various aspects of health-related problems and children's education, (3) it requires an increase in knowledge and skills among the people who are still very much left behind in the education sector so that their capacity is not much different from the current world development, (4) it is known that there are still many low education that has an impact on the work and income earned, thus showing that the community needs life skills that can be used to improve their standard of living, and (5) the community needs to be motivated to be more active as an effort to improve their standard of living.

Based on the analysis of urgent needs felt by residents of Sukorambi, the priority program for the solution was chosen. The programs in question are (1) equality, (2) literacy, (3) PAUD, (4) life skills, and (5) counseling.

Equality is chosen because equality education is non-formal education which includes package A equivalent to SD/MI, package B equivalent to junior high/MTs, and package $\mathrm{C}$ equivalent to senior high school/MA with emphasis on mastery, functional skills and the development of professional attitudes and personality of learning citizens. This program is intended for students who come from disadvantaged, non-school, drop out and drop-out communities, as well as productive age who want to improve knowledge and life skills. The program also serves other community members who need special services in meeting their learning needs as a result of changes in the improvement of living standards, science and technology.

Non-formal education itself according to the Indonesian Government Law and Regulation on education states that Non-Formal Education is a pathway to education beyond formal education which is carried out in a structured and tiered manner. Non Formal Education functions to develop students with emphasis, knowledge and skills 
and the development of a professional personality attitude. So that Equality Education is one of the educational units on the path of non-formal education which includes learning groups (pursuit) both Package A Program, Package B Program, and Package C Program which can be held through Learning Activity Studio (SKB), Center for Community learning activities ( PKBM), or other similar units.

The legality of pursuing packages $\mathrm{A}, \mathrm{B}$ and $\mathrm{C}$ has been guaranteed by the government in Law No. 20/2003 concerning the national education system which states that equality education is a non-formal education program that organizes general education that is equivalent to SD/MI, SMP/MTs, as well as SMA/MA which includes package A, Package B, and C packages. This is also reinforced in article 17 paragraph 2-3 which states that education equivalent to $\mathrm{SD} / \mathrm{MI}$ is a program such as package $\mathrm{A}$ and that which is equivalent to SMP/MTs is a package B program. While education equivalent to high school / $\mathrm{MA}$ is a program such as package $\mathrm{C}$ The legal basis for holding the $\mathrm{A}, \mathrm{B}$, and $\mathrm{C}$ packages is one of them is regarding government regulation number 73 of 1991 concerning outside school education and mutual agreement between the director general of out-of-school education and youth of the Ministry of National Education Republic of Indonesia and Director General of Islamic Institutions Ministry of Religion of the Republic of Indonesia number 19/E.MS/2004 and number DJ.II/166/04 concerning organizers equality education.

Literacy is chosen because of an approach or way to develop a person's ability to master and use writing, reading, counting, observing, and analyzing skills that are oriented to everyday life and utilize the potential that exists in the surrounding environment. For illiterate adults, literacy skills are not only able to read, write and count, but rather emphasize functions in everyday life (Archer, 1996). Broadly speaking, Literacy is defined as the basic knowledge and skills needed by all citizens and is one of the foundations for mastering other life skills.

Literacy programs in Indonesia are better known as Functional Literacy Education Programs, so that functional terminology in literacy is closely related to the function and / or purpose of learning in literacy education programs, and there is a guarantee that the learning outcomes are truly meaningful / useful or functional for improving the quality and standard of living of the learning citizens and their communities.

This program is intended to serve citizens who cannot read and write because they cannot attend or finish their education in formal schools. Based on cross-country research carried out by UNESCO, it was concluded that success in literacy programs had an impact on decreasing maternal and infant mortality rates, increasing the life expectancy of the community (Zainudin Arief, 1997).

Literacy education program is a form of Non Formal Education service to teach illiterate citizens, to have the ability to write, read, count and analyze, which is oriented to everyday life by utilizing the potential that exists in the surrounding environment, so that citizens can learn and improve quality and standard of living. 
PAUD is also chosen because PAUD is a necessity, but entering PAUD is a choice. The UNESCO program, which requires children to get pre-school education, is only intended for children to enter the school environment. The school environment is certainly different from the family environment and home environment. Your child may be used to queuing at home, for example alternating toys with cousins. But at school, he will face more people with more varied characters.

Development of children's character is also formed at an early age. Parents can see the tendency of the character and preferences of children assisted by formal education that applies discipline. That way, children can grow with their respective characters but still be able to follow the values and norms taught from school. From there it is expected that PAUD (Early Childhood Education) schools will be created to prepare children mentally before entering kindergarten or elementary school, and shape the character of children in the golden age. Including children to PAUD schools is very important, the goal is to form a basic framework for children to be able to adapt to an environment that is increasingly widespread and growing, to intervene early by providing educational stimuli so as to foster hidden potentials contained in children, sharpen the potential that has been seen in the child, so that the potential is channeled correctly, and detect early on the possibility of interference in the growth and development of the potential of early childhood Research also proves, children who have good readiness for school are more adaptable, thereby reducing the sense of stress they might feel. In this regard, we summarize the 10 benefits of PAUD schools as our consideration when registering your child into PAUD or TK, namely (1) Helping the formation of a child's brain structure, (2) Having better academic achievements, (3) In addition more structured daily activities of children, (4) Encouraging emotionalsocial development, (5) Learning discipline and following rules / commands pleasantly, (6) Encouraging children to dare to learn to write, read and count, (7) Encourage children's reading interest, (8) Encouraging self-confidence in children, (9) More prepared to enter higher school levels, and (10) Encouraging children to get better grades in secondary school.

Life skills education have different opinions, but the essence remains the same. Life skill is a continuum of knowledge and abilities needed by someone to be independent in life. Another opinion says that life skills are skills that must be possessed by someone to be happy in life. Malik Fajar (2002) said that life skills are skills needed to work in addition to skills in the academic field. Meanwhile the Broad Base Education team of the Ministry of National Education defines that life skills are skills possessed by someone to be brave and willing to face all life problems actively and proactively so they can solve them.od.

Life skill is education that provides basic provisions and exercises done correctly to students about the values of life that are needed and useful for the development of the lives of students. Thus life skills education must be able to reflect real life in the teaching process so that students obtain these life skills, so that students are ready to live in the midst of society. While the implementation of life skill 
education is varied, according to the condition of the child and his environment, but has the same general principles

Normatively, national education functions to develop capabilities and form dignified national character and civilization in order to educate the life of the nation, while the aim of Indonesian national education is to develop the potential of students to become human beings who believe and fear God Almighty, of noble character, healthy knowledge, competent, creative, independent and a democratic and responsible citizen.

Based on these objectives, the roles and functions and tasks of school education and out-of-school education are to prepare students to be able to: (1) develop life as individuals, (2) develop life for society, (3) develop life for nation and nation, (4) preparing students to attend higher education. The consequence is that what is taught must display the full figure of the four abilities. So to answer the above challenges, life skill education emerged as an alternative and effort to realize the national education goals.

Historically, Education has existed since humans existed on earth. When the life system is still simple, parents educate their children, or children learn from their parents or from the surrounding environment. Juridical Platform Life skill education refers to the Law of the Republic of Indonesia No. 20 of 2003 concerning the National Education System. Article 1 paragraph (1) describes education as a conscious and planned effort to create a learning atmosphere and learning process so that students actively develop their potential to have the power of religious spiritual strength, selfcontrol, personality, intelligence, noble character and skills needed by themselves, society, nation and state. So in the end the purpose of education is to help students to be able to improve and develop themselves as individuals and members of society in real life.

Slamet P.H (2014) provides hopes to be achieved in the application of life skills education among these expectations are: First, after receiving life skill education students have assets of inner quality, attitudes and actions that are ready to face future developments. Second, students have insight into career development, so they are able to choose, enter, compete and advance in the world of work. Third, students have the ability to survive in their independence and learn without guidance. Fourth, students have a level of independence, openness, cooperation and accountability which becomes their mental attitude so they are able to live happily in the midst of the times. Fifth, students have the ability to solve problems faced in their lives. The expected benefits of life skill education are twofold, the first is personal benefits for students, while the second is benefits for the environment in which students are located or for the wider community. The personal benefits of students include life skill education can improve the quality of thinking, heart quality and physical quality.

For the community life skills education can improve advanced and civil life with indicators of: increasing social welfare, reducing destructive behavior so as to 
reduce social problems and develop communities that are harmoniously able to integrate religious values, theory, solidarity, economy, power and art (taste).

The essence of counseling is non-formal education in changing target behavior in cognitive, affective, and psychomotor aspects in a better direction in accordance with their potential and needs. In counseling, the client or target is a subject, not the opposite being an object. According to Sumardjo (in Oos M. Anwas, 2011), the philosophy and principles of counseling in the true sense are participatory, dialogical, convergent and democratic, so that they empower, rather than extension practices, are top down, linear and contrary to philosophy of human development.

Counseling as a process of education or learning process means that the activities of disseminating information and explanations given can stimulate the process of behavior change carried out through the process of education or learning activities. That is, changes in behavior that occur / carried out by the target takes place through the learning process. This is important to understand, because behavior change can be done through a variety of ways, such as: inducement, giving incentives/gifts, or even through coercive activities (both through the creation of physical and socio-economic conditions, as well as coercion through rules and threats).

The results of the study on the procedures for analyzing the learning needs that have been carried out indicate that there are five programs that are needed in accordance with the considerations and agreements finally decided upon the five programs that were appointed as solution solutions.

According to Cole (1997) that the determination of the program needs to be agreed upon together is very important to do, because so that various parties have become part of the program to be implemented. Based on these reasons, assistance is provided for five learning programs, namely: (1) equality assistance program which aims to develop students with emphasis, knowledge and skills and the development of professional personality attitudes, (2) literacy assistance programs aim to educate illiterate citizens, in order to have the ability to write, read, count and analyze, which is oriented to daily life by utilizing the potential that exists in the surrounding environment, so that citizens of learning and society can improve their quality and standard of living, (3) auditing assistance program aims to form a basic framework ( foundation) for children to be able to adjust to an environment that is increasingly widespread and growing, to intervene early by providing educational stimuli so as to foster hidden potentials found in children, honing potentials that have been $t$ ampak in the child, so that the potential is properly channeled, and detect early on the possibility of disruption in the growth and development of the potential of early childhood, (4) life skill mentoring program aims to improve advanced and civil life with indicators indicators are: increasing social welfare, reducing destructive behavior so that it can reduce social problems and community development that are harmoniously able to integrate religious values, theory, solidarity, economy, power and art (taste), and (5) mentoring programs counseling aims to empower the community by empowering the 
community who are powerless and / or developing the power they already have into something more beneficial for the community concerned.

In the mentoring program activities can use methods and techniques that are in accordance with the real experience of the target audience as adults, with the aim of reducing difficulties and can facilitate the implementation. Ahmad Sanusi (in Amin Yusuf, 2014) states that the choice of methods, techniques and materials for activities in the community should be tailored to the needs and oriented to practical applications in life, so that they can provide greater benefits.

According to the principle of learning success in adults according to Rogers (Knowlees, 1979) can be observed from the change in behavior toward achieving adequate capacity. In this mentoring program, the changes that occur as a result of meeting learning needs occur in every citizen learning through interaction with other individuals to learn together with full confidence. Changes in behavior in terms of cooperation in various activities are the result of behavioral changes after the learning process.

Changes in behavior occur because of an increase and change in both knowledge, skills and mental attitudes through the fifth activity of mentoring programs for learning needs. According to Lunandi, A.G (in Amin Yusuf, 2014) adult education is not enough just to increase knowledge or skills, but must be equipped with confidence. Increased knowledge that is equipped with self-confidence so that it can encourage positive, real, comprehensive and sustainable change.

\section{Conclusion}

Based on the results and discussion of ideal agriculture-based family empowerment research conclusions can be formulated as follows: (1) there are a number of facts and needs that are felt namely the higher number of droup out and found that there are still many people who cannot read, write and count or term as illiterate communities that require an effort to optimize the quality and reach of ideal agricultural-based family empowerment services through non-formal education, (2) need to find ideal agricultural-based family empowerment methods through nonformal education to support new education learning for early childhood development , considering various aspects of problems related to health and education of children of age, (3) ideal agricultural-based family empowerment is needed through non-formal education to improve knowledge and skills among the people who are still very spelled out. living in the education sector so that it is needed so that its ability is not much different from the current world development, (4) it is known that there are still many low educated people who have an impact on employment and income, thus demonstrating that society requires ideal agricultural-based family empowerment through non-education -formal in life skills that can be used to improve living standards, and (5) the community needs to be motivated to be more active as an effort to improve their standard of living. and through various considerations and learning 
needs analysis established assistance programs for learning needs, namely equality, literacy, PAUD, life skills, and counseling.

\section{Bibliography}

Amin Yusuf. 2014. Analysis of Community Education Needs. Journal of Educational Research Vol. 32 No. 2 ISSN: 1978-8304. LP2M Semarang State University.

Badan Pusat Statis Badan Pusat Statistik Tik. 2017. Kelurahan Sukorambi Dalam Angka. Jember : Badan Pusat Statistik Kabupaten Jember.

Cole Kris. 1997. Crystal Clear Communica- tion. Terjemahan. Jakarta: Gramedia

Depdiknas. 2003. Undang-Undang No. 20 Tahun 2003 Tentang Sistem Pendidikan Nasional. Jakarta.

Oos M. Anwas. 2011. Competence of Agricultural Extension in Empowering Farmers. Journal of Mathematics, Saints and Technology, Volume 12 Number 1 March 2011, 46-55. Open University.

Rusmin Husain. 2011. The Role of Non Formal Education in Community Empowerment. Pedagogics Journal of Educational Sciences 2 (1) Vol: I Issue: I 2011.

Slamet PH. 2014. Andragogy and Heutagogy. Paper Presented at the Andragogy and Paedagogy Seminar and Workshop. Yogyakarta: Faculty of Engineering, UNY

Sylva Alkornia. 2018. Persepsi Orang Tua Mengenai Pelaksanaan Pendidikan Kesehatan Reproduksi Untuk Anak Usia Dini. Proceeding of ICECRS Volume 1 No 3 (2018) 231-240 Issn 2548-6160 (online).

Malcolm Knowles. 1979. The Adult Learning (Third Edition). Houston, Paris, London, Tokyo. Gulf Publishing Company.

Malik Fajar. 2002. Pendidikan Kecakapan Hidup (Life Skills). Bandung. PT Remaja Rosda Karya.

Michael Quinn Patton (Terjemahan Budi Puspo Priyadi). 2009. Metode Evaluasi Kualitatif. Yogyakarta. Pustaka Pelajar. 